\title{
Cephalothin in the treatment of syphilis
}

\author{
G. NICOLIS* AND A. LOUCOPOULOS \\ Venereal Disease Clinic, Salamis Naval Hospital, Greece
}

Although over 30 years have elapsed since penicillin was first used in the treatment of syphilis, it still remains the drug of choice. However, alternative drugs are necessary for those patients allergic to it. Good results have been reported after the use of tetracyclines, chloramphenicol, and erythromycin. However, prolonged courses of treatment with high dosages of tetracyclines, and especially with erythromycin, may sometimes be impossible because of the development of acute gastrointestinal disturbances.

The cephalosporins constitute a family of antibiotics which have been isolated from the fungus Cephalosporium acremonium. The cephalosporin nucleus, 7-aminocephalosporanic acid, contains a $\beta$-lactam ring identical to that of the penicillin nucleus. Semi-synthetic derivatives, e.g. cephalothin and cephaloridine, have been produced from this basic structure. Cephalosporins demonstrate bactericidal properties gainst both Gram-positive and Gramnegative bacteria and are little affected by penicillinase. Cephaloridine has been shown to have greater antitreponemal activity in rabbits than tetracycline and chloramphenicol, although less than penicillin (Flarer, 1967). Successful results have been reported from its use in small groups of patients suffering from early syphilis (Seftel, Sieff, and Richardson, 1966; Flarer, 1967; Gonzales-Ochoa and Moreno, 1967; Oller, 1967; Glicksman, Short, and Knox, 1968). However, there do not seem to be any reports of the use of cephalothin in the treatment of syphilis.

Owing to the similarity of their structure, there is a degree of cross-hypersensitivity between the cephalosporins and penicillin. Cephalosporins should not be given to patients who have suffered anaphylactic reactions after penicillin, and only after doing skin tests in patients that have had minor reactions to penicillin.

\section{Patients and methods}

25 male patients aged between 20 to 23 years suffering from primary or secondary syphilis were treated with

Received for publication October 16, 1973

$\star$ Address for reprints: Dr. G. Nicolis, 19 Scoufa Street, Athens 136, Greece cephalothin ('Keflin'). There were fifteen men with darkfield-positive chancres; seven of them had weakly positive serological tests. Seven other men had almost healed darkfield-negative lesions, but strongly positive serological tests. Three patients had a typical secondary rash and strongly positive serological tests. The treatment consisted of intramuscular cephalothin $1 \mathrm{~g}$. every 12 hours for 20 days in the cases of primary syphilis and for 25 days in the cases of secondary syphilis.

Wassermann reactions and Kahn tests were done every 2 months during the first year and every 4 months during the second. The duration of follow-up was 6 months for three cases of primary syphilis, but 2 years for the rest. Liver function tests and serum protein concentrations were unaffected by the treatment.

\section{Results}

In all cases the lesions healed rapidly. In those that initially had positive serological tests, the tests became negative within 3 months after the completion of therapy and remained so during the subsequent follow-up. The initially seronegative cases continued to be so.

\section{Conclusion}

The results indicate that cephalothin offers a satisfactory treatment for syphilis. Four of the 25 patients had had reactions to penicillin but did not react to cephalothin, so that the drug may be a useful alternative to penicillin in selected cases.

\section{Summary}

25 patients with primary or secondary syphilis were each treated with $1 \mathrm{~g}$. cephalothin by injection every 12 hours for 20 days (primary syphilis) or 25 days (secondary syphilis). Follow-up was from 6 months to 2 years and no recurrences were noted. The Wassermann reaction and Kahn test became negative and remained so. 


\section{References}

Flarer, F. (1967) Postgrad. med. F., 43, Suppl. Aug., p. 133

Glicksman, J. M., ShORT, D. H., and KNOX, J. M. (1968) Arch. intern. Med., 121, 342

GonZAles-OchoA, A., and MoReno, J. B. (1967) Postgrad. med. F., 43, Suppl. Aug., p. 134

OlLER, L. Z. (1967) Idem, p. 128

Seftel, H. C., SiefF, B. and Richardson, N. J. (1966) Med. Proc. (S.A.), 12, 29

\section{La céphalotine dans le traitement de la syphilis}

\section{SOMMAIRE}

25 malades atteints de syphilis primaire ou secondaire réçurent chacun des injections de $1 \mathrm{~g}$ de céphalotine toutes les 12 heures, pendant 20 (syphilis primaire) ou 25 jours (syphilis secondaire). Ces malades furent suivis de 6 mois à 2 ans, et aucune rechute ne fut observée. Les réactions de Wassermann et Kahn devinrent négatives et le restèrent. 